Marquette University

e-Publications@Marquette

Political Science Faculty Research and Publications

Political Science, Department of

$1-1-2001$

\title{
Who Pays for Health Care Reform?
}

Susan Giaimo

Marquette University, susan.giaimo@marquette.edu

Published version. "Who Pays for Health Care Reform?" in The New Politics of the Welfare State. Ed. Paul Pierson. Oxford: Oxford University Press 2001: 334-367. DOI. (C) 2001 Oxford University Press. Used with permission. 


\title{
11 \\ Who Pays for Health Care Reform?
}

\author{
Susan Giaimo
}

THE extraordinary post-war boom came to an abrupt halt in the mid1970s. The sluggish economic growth that followed ushered in a critical reexamination of the purposes and performance of the welfare state in all advanced industrialized societies. While social policy during the 'Golden Age' had aimed at expanding the scope and generosity of the welfare state and thereby redistributing the fruits of economic growth, by the 1980s and 1990s, 'retrenchment' had become the watchword. For many policy makers, business leaders, and research institutes, the welfare state had become synonymous with high costs and deteriorating economic performance. In their view, welfare state reform was critical to successful national or industry adjustment to tougher economic conditions (Pfaller, Gough, and Therborn 1991; OECD 1994d).

The "new politics of the welfare state" has also altered the relative position of various welfare state stakeholders. The views of those who finance the welfare state have steadily gained influence in policy debates, while those who provide and receive social benefits have increasingly found themselves on the defensive. Employers and government policy makers, and their interest in cost containment, have become the driving force behind welfare state reform.

Still, the project of containing welfare state outlays has been controversial. Such projects not only threaten the prerogatives of entrenched constituencies who benefit from social programmes (Pierson 1994), but also raise fundamental distributional concerns. Welfare states, after all, have sought to protect the vulnerable from the vagaries of the market (Polanyi 1944 [1957]: ch. 14). The critical questions surrounding the new politics of the welfare state, then, are whether payers' and policy makers' cost-containment projects have succeeded, and if so, whether the price of success has been the sacrifice of equity and solidarity. Have the burdens of welfare state reform and economic adjustment disproportionately fallen upon the shoulders of the weakest members of society, or have countries found ways to share this pain in a just fashion?

\footnotetext{
The phrase is taken from Pierson (1996).
} 
This chapter explores these questions through the lens of health care reform in Britain, Germany, and the United States since the late 1980s. Each country has a distinctive health care system. And each country undertook major reform initiatives designed to control health care outlays. Thus, Britain's National Health Service (NHS) is the model of a universal, state-administered health care system financed by general revenues; Germany has a statutory national insurance programme financed by employers and employees; while the USA relies primarily on voluntary, employment-based, fringe benefits to cover the majority of the workforce. Public programmes play a smaller role, covering only specified categories of the population. Looking at three different health care systems permits us to explore whether countries have converged on a common reform response in spite of their institutional variations, or whether institutional and political differences continued to shape reform paths in specific ways.

As this chapter will show, the three countries addressed the efficiency and equity goals in markedly different ways. Britain and Germany thus far have achieved good cost performance without surrendering the principle of universal access and without requiring the most vulnerable members of society to bear a disproportionate share of the burden of adjustment. Indeed, Britain's record on cost containment has been the best of the three cases. While the price has been explicit rationing of access to hospital care, Britain has done so in ways that address equity. Germany represents an intermediate case between Britain and the USA, spending more than the former but without resorting to the gaping inequities of the latter. The USA has only recently enjoyed markedly slower increases in health care outlays. But the cost-containment gains have come at the expense of worsening access to care for the sicker and poorer in society.

The reasons for these very different outcomes lie in the actions and preferences of payers and the state in each country. Specifically, payers' capacities to follow cost-containment strategies that were inimical to equity and solidarity depended on the health care system in which they found themselves, the political system and whether it provided them an avenue to influence health policies, and their own organizational capacity to pursue a unified, coherent line of action. In addition, because state actors had different roles in health care governance, they had varying expectations and capacities to ensure that cost-containment projects were compatible with equity. In brief, the universal health care systems of Britain and Germany blocked cost-containment strategies by payers or government actors that would have sacrificed equity, while the private, voluntary fringe benefits system of the United States, encouraged employers and insurers to take cost-cutting actions that worked in the direction of desolidarity.

The rest of the chapter proceeds along the following lines. Section 1 provides a broader background to situate the contemporary politics of health care 
reform. It explains how and why health care systems in Western countries have come under the stress of increasing cost pressures even as governments and employers have become more apprehensive about the possible effects of the welfare state on economic competitiveness. Section 2 develops the argument in greater depth. It explains how existing health care and political systems provide different opportunities or constraints for payers and the state to pursue unilateral cost-containment strategies, how health care institutions themselves shape policy preferences and strategies of payers, and how some systems require compromise solutions that reconcile equity with efficiency. Section 3 presents each country's case. The concluding section considers the broader lessons from health care reform for the contemporary politics of welfare state adjustment.

\section{TO SPEND MORE OR TO SPEND LESS? COMPETING PRESSURES ON HEALTH CARE SYSTEMS}

Payers' anxieties over rising health care costs are not unfounded. In general, health care has consumed a large and growing portion of social spending in all advanced industrialized societies, particularly in the past two decades. Beginning in the 1970s, health care systems experienced a 'cost explosion' that had the misfortune of coinciding with the global economic slowdown and concomitant worries about the fiscal viability of the welfare state.

However, our three countries did not fare identically. Britain has consistently been a low spender on the NHS when compared to its peers in the OECD. And having experienced a cost surge in the mid-1970s, Germany largely regained control over its health care outlays in the 1980s. The USA has had the greatest appetite for health care and remains at the top of the world league in health care spending (see Tables 11.1 and 11.2). The spending disparities are even more remarkable when one considers that both Britain and Germany have been able to extend access to care to the entire population while the USA has not.

Some of the reasons for escalating health care costs are, to varying degrees, common to all Western countries. First, the health sector is fertile ground for technological innovations that may prolong life but at considerable expense. In addition, once these discoveries are made, it is difficult - though not impossible - for insurers or governments to limit their diffusion, as patients demand access to such treatments (see Weisbrod 1985). Second, the populations of Western countries are graying, with direct consequences for health care. Older persons are likely to experience acute illnesses requiring high-tech interventions, or, more often, chronic conditions entailing long-term care. Both types of care do not come cheaply. At the same time, birth rates have 
TABLE 11.1. Health care spending as a percentage of GDP, 1960-97

\begin{tabular}{llcc}
\hline Year & Britain & Germany & United States \\
\hline 1960 & 3.9 & 4.8 & 5.2 \\
1965 & 4.1 & 4.6 & 5.9 \\
1970 & 4.5 & 6.3 & 7.3 \\
1975 & 5.5 & 8.8 & 8.2 \\
1980 & 5.6 & 8.8 & 9.1 \\
1985 & 5.9 & 9.3 & 10.6 \\
1990 & 6.0 & 8.7 & 12.6 \\
1991 & 6.5 & 9.4 & 13.4 \\
1992 & 6.9 & 9.9 & 13.9 \\
1993 & 6.9 & 10.0 & 14.1 \\
1994 & 6.9 & 10.0 & 14.1 \\
1995 & 6.9 & 10.4 & 14.1 \\
1996 & 6.9 & 10.5 & 14.0 \\
1997 & 6.7 & 10.4 & 14.0 \\
\hline
\end{tabular}

Source: OECD, Health Data (1998).

TABLE 11.2. Health care spending per capita, 1960-97 (\$lexchange rate)

\begin{tabular}{lrcc}
\hline Year & Britain & Germany & United States \\
\hline 1960 & 54 & 48 & 149 \\
1965 & 76 & 78 & 212 \\
1970 & 99 & 149 & 357 \\
1975 & 229 & 467 & 605 \\
1980 & 537 & 913 & 1,086 \\
1985 & 472 & 743 & 1,798 \\
1990 & 1,024 & 1,650 & 2,799 \\
1991 & 1,129 & 2,018 & 3,035 \\
1992 & 1,252 & 2,433 & 3,276 \\
1993 & 1,112 & 2,350 & 3,468 \\
1994 & 1,213 & 2,533 & 3,628 \\
1995 & 1,313 & 3,080 & 3,767 \\
1996 & 1,358 & 3,017 & 3,898 \\
1997 & 1,457 & 2,677 & 4,090 \\
\hline
\end{tabular}

Source: OECD, Health Data (1998).

failed to keep pace with increasing longevity, so that there will be fewer working-age persons in the future to shoulder the financial obligations associated with caring for their elders. Third, the health sector is a huge generator of service sector employment. But jobs in this sector tend to be labour-intensive and have lower productivity than the manufacturing jobs they are replacing. If Iversen and Wren (1998) are correct, the smaller growth rates associated with the shift to a post-industrial economy will only make the question of adequate financing of health care that much worse. 
Some of the causes for health care inflation, however, rest with the specific design of health care systems in individual countries. Fee-for-service arrangements for paying health care providers tend to be more inflationary than salary or capitation. The lack of a national budgeting mechanism to contain overall health care outlays is likely to produce cost-shifting rather than effective cost containment. Health care systems with multiple insurers tend to have higher administrative costs than single-payer systems. Some countries lack effective mechanisms to control the supply of specialists and hospitals and patients' access to them. Each of our countries has addressed (or failed to address) these issues in different ways. Section 3 addresses the particular problems they faced and their specific methods for dealing with them.

Regardless of their relative success or failure in ensuring cost discipline, governments or employers in the three countries believed that health care outlays posed immediate and long-term problems, and began to search for ways to address them. The reasons for such concerns are twofold. First, the developments exerting pressure to spend more on health care services have come at a time when economic growth has slowed from its historic post-war levels. This has raised concerns over how to finance current and future commitments in social spending, that is, whether mature welfare states can and will remain affordable. But the second concern has to do with the welfare state's impact on broader economic performance. While the exact date differed in each of our countries, from the 1980s and into the 1990s, the welfare state became inseparable from the question of national and firm-level adjustments to a more integrated and competitive world economy. In these debates, the welfare state was painted as a drag on or impediment to economic adjustment, and the solution seemed to be retrenchment measures of various sorts. ${ }^{2}$

Whether or how the welfare state has actually hurt economic performance may be open to question, but the change in the terms of political debate cannot be denied. The welfare state's impact on economic performance has become one of the most discussed topics among policy makers and academics, and has even spilled over into broader public discussions in Western

\footnotetext{
${ }^{2}$ However, different kinds of health care systems and welfare states appear to have different vulnerabilities in a more competitive and integrated economic environment. Where social provision is tied to employment, then the cost of fringe benefits or social insurance contributions has a direct impact on labour costs. Many analysts and employers recognize that high non-wage labour costs have adverse effects on employment, especially at the low end of the labour market (Scharpf 1997b). In voluntary fringe benefits systems, the problem of free-riding is rampant, and may place firms that provide benefits at a competitive disadvantage. Welfare states financed from general revenues can avoid saddling firms with higher labour costs. But they may present their own particular difficulties. Governments may have to raise taxes to levels that voters find intolerable, or choose to run expensive deficits and debts to cover spending commitments (see Genschel 1999; Pierson, Ch. 3 in this volume). If they opt for deficits, then governments run the risk of punishment by international financial markets, or exclusion from membership in regional economic clubs like Europe's single currency.
} 
countries. Concomitantly, payers' concerns over cost containment have carried greater weight in social policy debates than in previous decades.

\section{THE ARGUMENT: PAYERS AND THE POLITICS OF HEALTH CARE REFORM}

By the end of the 1980s, the terms of debate, the goals, and the relative power of different actors had shifted. Cost containment had become a priority of health policy, and the question of economic competitiveness cast a long shadow over the calculations of policy makers and employers alike. Still, in some countries, the politics of health care reform required employers and state actors to forge negotiated settlements that accepted some cost control pain in exchange for equity gains (see also Bonoli, in this volume; Rhodes, in this volume). In other countries, however, such exchanges were absent, and the pursuit of cost control came at the expense of equity.

To explain these different outcomes, we must know who the payers were, what they wanted from health care reform, and what they were able to achieve in that regard. Whether payers were employers or the state, their policy preferences depended on whether they viewed the existing health care system as a help or a hindrance to their broader strategies of economic competitiveness. Furthermore, each country's health care system either granted or denied employers, insurers, or the state opportunities to take unilateral action to contain their own health care outlays at the expense of other stakeholders. In addition, the political arena provided different avenues for payers and other stakeholders to influence the course of health policy. Formal political institutions, contingent electoral outcomes, and the organizational characteristics of interest groups representing critical stakeholders worked to produce a particular brand of health care politics in each country.

The most critical variable, however, was whether the health care system was a universal, statutory system or not. If a country's health care system legally guaranteed a universal right to health services, then it placed serious constraints on unilateral cost-cutting strategies by either the state or employers. Such systems created broad constituencies or other countervailing actors to check employers' or governments' efforts at one-sided cost-shifting. The critical role of employees or taxpayers in financing or administering health care programmes granted them as much legitimacy as policy makers or employers in health care reform debates, while the political system provided them additional means of influence over the content of reform policies. In addition, because universal health care systems institutionalized equity and redistribution in their core design (see Stone 1993: 292), they made efforts to shift the burden of cost containment on to those least able to shoulder 
it politically difficult; such attempts were viewed as morally unjust. But while universal systems placed a heavy obligation on state actors to guarantee their solidarity, they also granted the latter the means to govern the behaviour of health care actors to ensure their compliance with both efficiency and equity. Voluntary fringe benefits systems, by contrast, contained none of these mechanisms or countervailing actors to constrain the behaviour of employers or insurers. If anything, it was government actors who found their freedom of manoeuvre and their authority over private actors in the health care system severely circumscribed. The three countries help elaborate the different parts of the argument.

First, each country's health care system designated different actors as payers and provided them with different capacities to realize their costcontainment goals. Thus, in Britain's National Health Service (NHS), the state is responsible for financing and providing health care. Its status as a single payer would seemingly grant the state unlimited freedom to decide health policy. But in fact there are limits: the state must answer to taxpayers who ultimately finance the health care budget. In Germany, employers and employees have equal responsibility for financing and administering national health insurance. Because both employers and unions are firmly embedded in these arrangements, it is difficult for one side to take unilateral action against the other. In addition, the statutory nature of health insurance closes off the option of 'exit' by employers, since they must provide insurance to their workers. In the USA, employers have been the pivotal players and payers in the politics of health care reform because most Americans obtain health insurance as a company-based fringe benefit. At the same time, employers are free to provide or withhold fringe benefits, since these are voluntary. And since employees and unions lack an institutionalized role in health insurance financing or administration, they have not been able to mount an effective opposition to employers' cost-cutting strategies. Lastly, many employers have viewed government efforts to intervene in the private fringe benefits system as an illegitimate intrusion in corporate governance. Second, in addition to the health care system, the political arena has offered payers an alternative or complementary channel of influence over the course of health care reform. In Britain, taxpayers have two means of influence. One is the ballot box, which, admittedly, is a blunt instrument wielded infrequently. But the other is through members of parliament who regularly grill the government on the performance of the NHS. These accountability mechanisms partially offset the tendency towards a politics of imposition that the centralized political system encourages. In Germany, both employers and employees have found the various political parties to be willing advocates for their views. Coalition governments and parties associated with specific health care clients have made compromise and the balancing of the countervailing interests of employers and employees the 
norm in health politics. Federalism, too, has sometimes provided health care actors with an additional means of influence. In the USA, the fragmented political system - especially separation of powers - has provided employers ample opportunities or 'veto points' (Immergut 1992; Steinmo and Watts 1995 ) to influence the course of health care legislation. But while they may be good at wielding the veto, employers have been hampered in their ability to take positive, unified action by their organizational fragmentation in the political arena. In fact, the business 'community' is a misnomer that masks the reality of competing peak associations with few if any sanctions over wayward members. As David Vogel (1978) has pointed out, most business leaders tend to think of policy questions in terms of the interests of their own firm rather than of the business community as a whole. The weakness of American business as a collective actor in the political arena mirrors the autonomy of individual enterprises and the multiple cost-cutting options available to them in a private, voluntary fringe benefits system.

Third, statutory, universal programmes make the pursuit of cost containment at the expense of equity difficult, while voluntary fringe benefits systems do not. One reason for this is that universal systems create broad constituencies with a stake in preserving the quality and comprehensiveness of benefits. To put it bluntly, middle-class beneficiaries find themselves in the same risk community as the poor, but their reasons for fighting to protect these programmes from retrenchment may arise from simple selfinterest rather than out of any sense of justice or altruism towards the less fortunate. Add to this the reality that the middle and upper classes tend to be more active in politics than the poor (though this is truer in the USA than in other countries), then the risk of electoral retribution for major retrenchment is high. Moreover, universal programmes carry legitimacy in the public eye because the majority of beneficiaries make some sort of contribution to them, either through payroll deductions to social insurance or through general revenues to finance a national health service. Benefits take on the status of entitlement based on contributions. Indeed, in some countries, courts have ruled that benefits are akin to property rights to be safeguarded by law (see Myles and Pierson, in this volume). Thus, the political risks are high for governments that launch retrenchment policies that appear to threaten the entitlements of a formidable range of stakeholders.

However, universal health care programmes go well beyond an appeal to self-interest or entitlement based on past contributions. In fact, they are the most redistributive of social insurance programmes, creating broad solidarities that encompass equity and that protect the more disadvantaged members of society. Unlike pensions and unemployment insurance programmes, in which benefits are calculated on the basis of past contributions and earnings, the universal health care programmes in Britain and Germany incorporate substantial redistribution through the pooling of risks. They 
involve cross-subsidies from richer to poorer, younger to older, healthier to sicker, men to women (Hinrichs 1995; Stone 1993: esp. 290-2). And despite differences in their institutional arrangements, the health care systems in both countries approach Marshall's (1963) ideal of social citizenship, whereby each person has a right to a decent social minimum as a necessary precondition for full participation and membership in the larger community. ${ }^{3}$ In both Britain and Germany, definitions of social citizenship and a decent social minimum have been generously drawn to mean that every person has a right to the same level of high-quality care, based on one's medical need, not on one's ability to pay or past contributions. By contrast, two-tiered systems of provision based on ability to pay, which grant generous services for the wealthy and only residual benefits for the poor, violate the universality and comprehensiveness of social citizenship and their associated notions of equity.

In short, the universal health care systems of Britain and Germany equate equity with equality. Equity is defined as a broad solidarity, in which the poor and sick have the same status as the wealthy and healthy. This equation derives from the ideas of mutuality and reciprocity that underpin social insurance: people identify with each other in recognizing that they all share a risk of becoming ill or incapacitated, and respond by pooling their risks against this vulnerability (Baldwin 1990; Stone 1993). In doing so, universal programmes incorporate equity by extending their reach to include the disadvantaged with the better off and tying them together in a common fate. Put another way, these programmes achieve the goal of equity by 'targeting within universalism' (Skocpol 1991). ${ }^{4}$ The institutionalization

${ }^{3}$ Baldwin (1990) points out that universalistic, tax-financed programmes are more solidaristic because they consider the nation as the risk pool, while social insurance programmes segment risk pools along class, occupational, or regional lines. However, even in Germany's national insurance programme, the broader conception of solidarity has taken root. In the past two decades, the state has mandated that the sickness funds offer approximately similar benefits (on the basis that all are entitled to medically necessary care). And the 1993 reforms introduced a financial risk-pooling scheme among blue-collar and white-collar funds (see below and also Giaimo and Manow 1999).

${ }^{4}$ The debate between universal and targeted programmes as a more effective and efficient way to address the problems of the disadvantaged is not new. Skocpol echoes past advocates of universal programmes by arguing that such arrangements better address the needs of the poor because they have broader political support and higher levels of funding that residual programmes lack. Thus, she calls for universal rather than targeted programmes as the best way to meet the needs of the disadvantaged. Titmuss saw the dilemma between targeted and universal programmes as a key challenge of modern welfare states. However, he supported selective benefits targeted to needy groups in addition to universal programmes. In his eyes, a broader framework of universalism and a language of social rights were prerequisites to for targeted programmes to escape stigma. A universal framework was needed because it "provides a general system of values and a sense of community; ... sees welfare, not as a burden, but as complementary and as an instrument of change and, ... allows positive discriminatory services to be provided as rights for categories of people and for classes of need in terms of priority social areas and other impersonal classifications' (Titmuss 1987b: 154). 
of risk-sharing behaviour through social insurance thereby reinforces values of sharing and community among the population. Universal programmes thus rest on multiple bases of legitimacy that are broadly shared - from a notion of justice grounded on one's full inclusion in the community of social citizenship, through ideas of reciprocity and mutualism, to simple self-interest in preserving one's own entitlements-that together prove quite resistant to challenges of retrenchment. ${ }^{5}$

With social insurance, then, self-interest is compatible with reciprocity and pooling of risks. But self-interest can just as easily be conceived of in narrower terms, as 'one gets what one pays for'. This expresses the logic of actuarial fairness practised by private insurers. Actuarial fairness maintains that those who are healthier have no obligation to cross-subsidize those who are sick. Rather, insurance premiums should only reflect one's expected or actual use of health care. In practice, this kind of 'justice' encourages all sorts of inequities. Private commercial insurers, following the dictates of profit maximization and actuarial fairness, segment the market, 'cream skim' the healthier and wealthier patients, since they are the least costly to insure, and shun the unprofitable, expensive cases, namely, the sicker and poorer (Stone 1993). In sum, and in contrast to Britain and Germany, the private and voluntary nature of employee fringe benefits in the USA produces rampant inequities. Both employers and insurers are free to 'opt out' and refuse to cover the poorer and sicker on the grounds of competitiveness or profit.

Finally, statutory universal programmes and private fringe benefits systems affect state actors' freedom of manoeuvre as much as that of employers. In universal systems, the state has the legal obligation to guarantee that all citizens have access to comprehensive health care. This obligation holds not only in a nationalized health service like Britain's, where the state is the payer, but also in a social insurance system like Germany's, where the state is not. Such obligations have set political limits to how far governments could push retrenchment and whether they could do so in ways that burdened the most vulnerable. But at the same time, the statutory systems of Britain and Germany have provided governments with the legal authority and institutional means to set the parameters of the system and ensure that health care actors' quest for cost control did not destroy equity and solidarity. The government in London could use the hierarchical administrative apparatus

Social insurance programmes might also incorporate (or least be compatible with) other motives or norms besides self-interest or mutual obligations and rights. Such programmes might also reflect a belief that in a civilized society, the stronger members have a responsibility to help the weaker, which would be expressions of paternalism or altruism. Nevertheless, Baldwin (1990) rightly points out that social insurance rooted in reciprocity removes the stigma and dependence of charity and instead accords benefits based on social rights or equal status in the risk community. 
in the NHS to shape the pace and content of its reform programme in implementation, while the federal government in Germany could mandate new implementation tasks and rules on public-law bodies of insurers, providers, employers, and employees. But in the private employer-based health insurance system of the United States, government actors were denied the legal authority and the institutional linkages to prevent employers and insurers from following a range of go-it-alone cost-containment strategies that have burdened the weaker members of society. Businesses and insurers have viewed government efforts to regulate the health care system as an illegitimate intrusion in their private domain, while the peculiarities of regulatory federalism have militated against coherent government action in this area.

The experiences of health care reform in Britain, Germany, and the United States presented below bear out these conclusions.

\section{THE CASES}

\section{Britain: The Limits of Neoliberal Reform in a Universal Health Care System}

In Britain's NHS, the state plays a predominant role in financing and providing health care. Health care is financed from general revenues and the central government determines the NHS budget. The state owns the hospitals and governs the health service through successive tiers of heath authorities emanating from the Department of Health (DOH) at the centre. At the same time, state managers have shared authority in health care governance with the medical profession, granting the British Medical Association (BMA) an important role in policy making and administration (Giaimo 1994, 1995). British governments have also relied on hospital doctors to ration scarce resources through waiting lists for non-emergency hospital services. This amounted to an 'implicit concordat' with the medical profession, whereby doctors took on the unpleasant task of rationing and agreed to refrain from questioning governments' budgetary decisions; in exchange, policy makers did not question their clinical freedom (Day and Klein 1992: 471; Klein 1989: 235).

Britain's health care reform debates in the 1980s and 1990s were not couched in terms of high labour costs because the NHS was financed from general revenues rather than payroll taxes. And Britain had a very respectable record of cost containment. Its fiscal discipline owed to global budgeting of health care and limiting the number of hospital beds and specialist physicians. The NHS also relied on general practitioners to act as gatekeepers to hospital 
and specialist care, and rationed elective surgical and hospital procedures by means of waiting lists based on medical need. ${ }^{6}$

Still, the costs and effects of the welfare state on Britain's economic health remained an issue for Margaret Thatcher. Thatcher's disdain for the health service reflected her neoliberal distrust of 'big government' and collectivist politics generally, both of which she saw as responsible for Britain's economic decline. $^{7}$ And containing health care outlays was part of her broader agenda to bring public spending under control (Harrison 1988: ch. 5) and unleash private economic initiative to bring about Britain's economic regeneration.

Thatcher thus subjected the NHS to a severe austerity regimen throughout the 1980 s. $^{8}$ But as Klein (1995) observed, the Prime Minister's success in holding down health care spending exacted a high political cost, provoking a bitter public quarrel with Parliament, health policy experts, and the medical profession. As waiting lists grew and hospitals closed wards and cancelled operations, critics charged that the government's 'underfunding' policy was starving the health service of needed funds, charges which only fuelled public fears that the NHS was not 'safe in the Conservatives' hands'. Thatcher countered that inefficiencies in delivering health care, rooted in unaccountable doctors and managers eager to defer to them, were responsible for the burgeoning waiting lists. But with public criticism mounting, she initiated a full-scale review of the NHS in 1988.

The political system and the policy making process offered her the luxury to consider a range of radical proposals and to enact her reforms with relative ease. First, the review was a secretive affair involving Thatcher, a few trusted advisers, and outsiders whose political views mirrored her own. It was a break from the royal commissions of her predecessors, which had included all relevant interests. Second, party discipline and a huge parliamentary majority reassured Thatcher that her legislation would be enacted by Parliament.

But even with these political advantages, Thatcher discovered that there were limits to her reform ambitions, at least on the question of radically

${ }^{6}$ However, Aaron and Schwartz (1984) found that some procedures were rationed on social grounds rather than strictly clinical criteria.

${ }^{7}$ For the neoliberal critique of Britain's decline and accounts of the rise of the New Right in Britain, see Gamble 1994: ch. 2; Jenkins 1987; and D. Kavanagh 1990: esp. chs. 3 and 4. According to neoliberals, 'big government' and 'special interests' stifled individual initiative and economic growth. In Thatcher's eyes, the NHS epitomized these twin evils: it was a sprawling public bureaucracy full of rigidities, dominated by a medical profession unaccountable to elected officials, managers, and consumers.

${ }^{8}$ NHS spending increased $3 \%$ per year in the 1980 s. But this rate was much lower than in previous decades and below what health care experts considered sufficient to keep up with technological advances, population ageing, and medical need (Ham, Robinson, and Benzeval 1990: 12-14; Klein 1995: 142).

${ }^{9}$ For an account of the health care debates in the 1980s, see Klein 1995 and Giaimo 1994. 
transforming the financing arrangements for health care. The review team considered but rejected radical proposals for compulsory national insurance or mandatory private insurance on the grounds that the economic and political costs would have been prohibitive: both of these options would have done far worse in controlling health care costs than the centralized budgets and administrative simplicity of the single-payer NHS. And for all its shortcomings, the NHS was the most popular element of the British welfare state. Thatcher gauged that dismantling it would have only invited the retribution of voters (Timmins 1995: 392-4; 453-65). ${ }^{10}$ In addition, national insurance would have shifted the cost of health care onto employers and almost certainly provoked their opposition. And it would have undercut her strategy to attract inward investment and aid industry competitiveness through low labour costs.

With privatization off the table, Thatcher decided that she would instead bring the market into the NHS itself. Hence, the 1989 White Paper called for an 'internal market' in the NHS, which split purchasers from providers. NHS hospitals were granted independence from district health authorities (DHAs). But hospitals now had to compete with each other and with the private sector for the patients of DHA purchasers or those of general practitioner fundholders. Fundholders were large, office-based, primary care physician practices that accepted a budget to purchase certain diagnostic and elective hospital procedures for their patients for which long waiting lists existed. In addition to the market reforms, the government also granted NHS managers a range of monitoring controls over doctors, from job descriptions to mandatory physician peer review, to ensure that doctors provided more cost-effective care (UK Department of Health 1989). The government hoped that competition would not only yield more efficient health care delivery but would also devolve responsibility for NHS performance failures down to local purchasers and providers.

In practice, however, the central state exerted tight control over the internal market. Thatcher's successor, John Major, streamlined the administrative tiers in the NHS, thereby increasing the capacity of ministers and managers at the centre to intervene in the day-to-day administrative

${ }^{10}$ A proposal for private health insurance that the Prime Minister's policy unit floated in 1982 met with fierce media criticism and public outcry, prompting Thatcher to disavow it (see Timmins 1995).

Thatcher's health care reforms thus differed from her policy towards state earnings-related pensions, which she gradually phased out (see Myles and Pierson, in this volume). But her caution in health policy was not only because the NHS was less expensive than other alternatives. Rather, the political risks of switching to a new health care system were considerable. The contrast with SERPS pensions is instructive. Unlike the NHS, which was more than 40 years old and upon which most Britons relied for health care, SERPS was an immature programme with relatively few pensioners dependent on it. Thus, the political and financial costs of phasing out SERPS were smaller in comparison to the NHS. 
decisions of local units. And both he and Thatcher designed the market so as to limit the scope of competition among providers in order to ensure that they would not shy away from treating sicker, more expensive patients. ${ }^{11}$ In some cases, this meant pre-empting market forces altogether, as with Major's decision to pursue a centrally directed rationalization policy for London hospitals rather than allow disruptive market forces to decide the winners and losers (see James 1995). For their part, health service purchasers and providers preferred co-operative, longer term contractual relationships than the one-off encounters characteristic of a spot market that the Thatcher Government had envisioned (Light 1997).

How can one explain the continued presence of the state in the market, and the very limited competition that was permitted? While the formidable technical difficulties of creating a market from scratch required detailed guidance and intervention from the NHS Executive, political considerations proved a more powerful brake on the market. First, the universalism of the NHS created a broad constituency with a stake in assuring access to quality care. Any cost-cutting programme that threatened a steep and visible decline in quality risked punishment at the polls from middle-class (and workingclass) voters. Second, the universal citizenship rights in the NHS created a broad solidarity and commitment to equity that the public expected the government to guarantee. More than any other branch of the British welfare state, the NHS has epitomized - or has at least aspired to - a comprehensive notion of community based on Marshall's (1963) idea of social citizenship, and has expressed this solidarity as the right of all to a comprehensive level of care, (nearly) free of charge, on the basis of clinical need rather than on ability to pay (Klein 1995: ch. 1; Ministry of Health, no date; Speller 1948; Titmuss 1974, 1987a, b). ${ }^{12}$ The deep attachment to the solidarity of the NHS not only ran strong within the Labour Party (which, after all, had created the health service), but also among the Tory wing of the Conservative Party that was sympathetic to state intervention in the economy and in social welfare. All of these political considerations compelled the Conservatives to carefully craft and constrain the workings of the internal market to avert the most egregious inequities and chaos that unbridled competition would have unleashed.

"Thus, the government limited GP fundholders' financial liability and the range of hospital services they could purchase, restricted the freedom of hospitals and fundholders to dispense with their 'profits', and mandated the development of a capitation system for purchasers that would adjust for inequities based on patients' health status (Maynard 1991; UK Department of Health 1989).

${ }_{12}$ Indeed, opinion polls have consistently shown that the public remains strongly committed to the principles of tax-financed, universalistic, and publicly provided health care and willing to pay higher taxes for health care (Klein 1995: 135-6, 240; Taylor-Gooby 1991: ch. 5). 
Finally, the centralized structures of both the NHS and the political system made it hard for the government to 'let go' once the market was in place. Because the central government provided health care and determined the budget of the NHS, it had a direct stake in how that money was spent. Government ministers had to deal with the Treasury's perennial concerns over 'value for money', and Parliament's concern for the level of quality of services. Ministers had to face the regular grilling of members of Parliament (MPs) during parliamentary question time, and were held accountable for the performance failures even in the far-flung reaches of the NHS. Government ministers deemed it intolerable to cede control to lower level managers or to freewheeling market forces, while still being held responsible by voters and MPs.

And even as the NHS placed a heavy obligation on politicians to safeguard the equity of health care provision as they pursued cost containment, it also granted them the means to do so. The statutory guarantee of universal access gave government officials the authority to set rules on the behaviour of purchasers and providers in the health care market to ensure that their competitive behaviour did not come at the expense of the sickest and most costly patients. At the same time, the hierarchical tiers of health authorities served as the conduit through which the central government controlled the introduction and subsequent development of market forces in the NHS.

How well, then, did Conservative governments uphold their role as guarantor of equitable access for all while pursuing cost containment? On the question of equity, the record is mixed. On the one hand, the internal market reforms did not produce enough efficiency gains to make waiting lists noticeably diminish, much less disappear. In and of themselves, waiting lists do not offend equity, since one's place in the line is based on medical need. But since the inception of the NHS, those with private insurance have been able to jump ahead of the waiting lists for elective surgery. This inequality of access between those with private and public coverage has long been a point of contention in health politics, and only grudgingly tolerated by Labour politicians. Still, the extent of this inequity is often exaggerated. The segment of the population with private insurance has always been a small minority; in 1990, only 11 per cent of the population had private coverage (Klein 1995: 155; Timmins 1995: 507). Moreover, private coverage has served more as a 'safety valve' for unmet need, rather than providing the middle class a path of permanent exit from the public system. Those with private insurance still receive most of their care from the NHS as public patients, because private policies are restrictive in their scope of coverage, and tend to be confined to profitable elective procedures and amenities like private hospital room and choice of specialist (Klein 1995: 155-7; Timmins 
1995: 507). ${ }^{13}$ This means that the bulk of the population accepts (even if unenthusiastically) rationing of non-emergency hospital treatment through waiting lists whose criterion is medical need. The question for British policy makers is whether limiting access to non-emergency treatments still imposes suffering and reduced quality of life for those on the lists.

A greater criticism is that the internal market's fundholding scheme introduced a new kind of inequity of access among NHS patients themselves. Now, the wait for elective surgery was no longer solely a question of medical need but also of the ability of one's purchaser to pay. While the evidence was by no means definitive, it suggested that larger fundholding practices used their budgets and business savvy to achieve faster services for their patients than did non-fundholding practices. ${ }^{14}$

On balance, however, the NHS has weathered the changes of the internal market to retain much of its egalitarianism and universalism, and the Conservative reforms represented a quite limited challenge to solidarity. Universal access to medically necessary care remains a statutorily guaranteed, social right of citizenship. And as noted above, policy makers have taken great care to limit the play of market forces in the NHS to avoid flagrant inequities. Thus, fundholders and providers in the internal market operate under a number of constraints that discourage or prevent them from skimming the best patients. Moreover, the Blair Government's intention to abolish fundholding would presumably eliminate the threat that the scheme posed to equity. ${ }^{15}$

${ }^{13}$ Private insurance covered $6.4 \%$ of the population in 1980 , rising to $11.5 \%$ in 1989 . Twentythree per cent of employers and managers had private insurance at the end of the $1980 \mathrm{~s}$, while $27 \%$ of professionals did (Klein 1995: 155). Private insurance was also a company fringe benefit highly dependent on the health of the economy; in the recession of the early 1990s, private insurance coverage stagnated. Among those with private insurance, more than half of their in-patient stays and $80 \%$ of their out-patient stays were covered as NHS patients (Timmins 1995: 507). Finally, while the number of private hospitals and providers increased, and the proportion of spending on institutional care rose from less than $10 \%$ in 1986 to $19 \%$ in 1993 , most of this growth was in the area of nursing home care, which the NHS did not cover anyway (Klein 1995: 158-60; Timmins 1995: 507).

Waiting lists rose from 700,000 in 1992 to nearly 1.3 million by 1998 ('Bevan's Baby Hits Middle Age', The Economist, 4 July 1998, 56).

${ }^{14}$ Different contracts used by health authorities and fundholders accounted for some of the differences in access to hospital care (British Medical Journal, 12 Dec. 1992, 1451; 23 Jan. 1993, 227-9; Whitehead 1993). But some observers countered that fundholding had 'spillover' effects that benefited all patients, and pointed to health authorities that consulted non-fundholding GPs in their purchasing decisions or that devolved purchasing decisions to them (Klein 1995: 241-2).

${ }^{15}$ Fundholders will be replaced by larger primary care groups involving all GPs, who will purchase an array of services on behalf of DHAs for a population area of up to 100,000 patients. The Blair Government's proposals also indicate that it will continue with the centralizing tendencies of the Thatcher-Major reforms. The NHS Executive will have greater capacity to monitor doctors' practice patterns and intervene in the local decisions of managers and practitioners if deemed necessary (see Klein 1998; UK Department of Health 1997). 
But did the market deliver the hoped-for cost discipline? The NHS has maintained its impressive record on containing costs relative to other OECD countries, but this is less a result of market competition than the effectiveness of other policy instruments. In areas with multiple providers, the NHS has become more responsive to patients or their fundholder agents. And as a whole, more patients have been treated (Klein 1995). But the internal market has been expensive to create and administer: it has generated substantial transaction costs in terms of administrative personnel, and required generous financial inducements for GPs to take up fundholding. In any case, such generosity proved fleeting, as the Major Government subsequently resorted to a policy of austerity. ${ }^{16}$ Thus, the remarkable cost discipline of the NHS has been less an achievement of market efficiencies than of policy makers' willingness to deploy the weapon of tight global budgets and the public's tolerance of waiting lists in a government-created context of scarcity.

\section{Germany: A 'Socially Bounded Market' within Corporatism ${ }^{17}$}

Germany's compulsory national insurance system covers 90 per cent of the population through a network of approximately 500 quasi-public sickness funds (Krankenkassen) organized on class, occupational, and regional lines (Giamo and Monow 1999: 982). Despite their organizational differentiation, the sickness funds provide similar benefits packages as mandated by law. Employers and employees finance health insurance contributions in equal shares and have a role in health care administration through parity representation on the sickness funds' boards. ${ }^{18}$ In granting employers and employees equal roles in financing and administration, the German health insurance system has institutionalized the idea of countervailing power in its very design.

Although the state does not finance health care, corporatist governance accords it a critical role in regulating the behaviour of sectoral actors and

16 The number of managers soared from 700 in 1987 to over 13,000 in 1991. Between 1991 and 1992 , there was an almost $25 \%$ increase in managerial personnel while only a $1 \%$ rise in hospital medical staff (Pike, 'NHS Managers' Wage Bill Soars', Financial Times, 5-6 Sept. 1992, 4; Pike, 'Rise of 25\% in NHS Managers', Financial Times, 11 Dec. 1993, 6). The Blair Government calculated that managerial costs had risen from $9 \%$ to $12 \%$ (Klein 1998). GP fundholders initially received financial sweeteners to encourage their take-up in the scheme, though such payments were later discontinued (Sherman, '16,000 Pounds for BudgetHolding GPs', The Times, 14 Dec. 1989, 22). Critics charged that the amounts devoted to management merely siphoned off resources from direct patient care. Following its early generosity, the Major Government subsequently kept NHS spending increases well below the rate of inflation. Thus, NHS spending was projected to rise a mere $0.3 \%$ from 1996 to 1999 ('An Unhealthy Silence', The Economist, 15 Mar. 1997, 57).

17 The title is borrowed from Henke (1997).

18 The boards of the sickness funds set the level of contribution rates, though in practice that power is circumscribed by law: the sickness funds cannot run long-term deficits, so their contribution rates must cover their health care expenditures. 
setting out the overall objectives for the system. Through the instrument of framework legislation, the government sets out broad policy goals and rules for the health care system but then delegates the job of implementation to quasi-public associations of sickness funds and physicians (Kassenärztliche Vereinigungen, or KVs) at the provincial level. Guided by the principles of subsidiarity and self-governance by sectoral actors, the state does not usually intervene directly in health care administration. But if sectoral actors refuse to implement the terms of the law, then the state may exercise its reserve powers of intervention until doctors and insurers prove able and willing to fulfil their public obligations. Once they do, the state pulls back and allows them to reclaim their collective rights of self-governance (Giaimo 1994, 1995; Giaimo and Manow 1999; Streeck and Schmitter 1985).

As part of its authority to set the parameters of the health care system, the state mandates that all employers offer insurance to their workers with incomes below a certain ceiling, finance contributions in equal shares with employees, and share with them in the administration of the sickness funds. In addition, the state also devises cost-containment policies that health care system actors are required to follow. For example, hospital doctors are salaried, while office-based practitioners must live within the confines of a regional or state-level budget cap for their services as negotiated by provincial-level associations of physicians and insurers. ${ }^{19}$ In addition, providers and insurers are legally required to align their collective bargaining agreements with the principle of stable contribution rates (Beitragssatzstabilität). However, as we shall see, the state sometimes has difficulty getting doctors and payers to follow these provisions in their collective agreements.

Because health insurance is employment-based, rising health care costs have always had a direct effect on labour costs. But Germany's bleaker economic conditions in the past decade have placed serious strain on a welfare state financed from payroll contributions. The worldwide recession of the early 1990 s, along with the costs of German unification, drove up the demand for unemployment insurance, while firms increased their use of early retirement and disability pensions to shed older and less productive workers (Manow 1997a). ${ }^{20}$ Unemployment and labour force exit meant a smaller base of wages and salaries from which to finance growing demands for social insurance, so that by 1996 , social insurance contributions had risen to nearly 41 per cent of wages (OECD 1996d: 76, and see Table 11.3). At the same time, German firms were coming under considerable competitive pressures from

19 Ambulatory physicians receive fee-for-service reimbursement, but their level of payments may be adjusted downward over the course of the year in order to remain within the cap.

${ }_{20}$ The welfare state accounted for approximately $18 \%$ of the transfers to eastern Germany up through 1995, largely for unemployment benefits and early retirement pensions. Not surprisingly, these funds incurred enormous deficits as a result (see Heilemann and Rappen 1997: 13, 15). 
TABLE 11.3. Social insurance and health care contribution rates in Germany, 1960-96 (as \% of gross wages)

\begin{tabular}{lll}
\hline Year & $\begin{array}{l}\text { Employer-employee } \\
\text { joint contribution rate } \\
\text { to social insurance }\end{array}$ & $\begin{array}{l}\text { Average contribution } \\
\text { rate to sickness funds }\end{array}$ \\
\hline $1960^{\text {a }}$ & 24.4 & 8.4 \\
1970 & 26.5 & 8.2 \\
1975 & 30.5 & 10.5 \\
1980 & 32.4 & 11.4 \\
1985 & 35.1 & 11.8 \\
1990 & 35.6 & 12.6 \\
$1993^{b}$ & 37.4 & 13.4 \\
1995 & 39.3 & 13.2 \\
1996 & 41.0 & 13.6 \\
\hline
\end{tabular}

" 1960: blue-collar workers' funds only; after 1960, all funds.

b Since 1991, western German states only.

Source: Manow 1997a: Federal Ministry of Labor.

globalization and the completion of Europe's single market. As a result, employers began to call upon government to stabilize social insurance outlays in order to help them bring their labour costs under control. In this they found support from scholars and policy makers who argued that high social insurance contributions were partly responsible for pricing labour out of the market, especially in lower productivity services (Esping-Andersen 1996c; OECD 1996d: ch. 3; Scharpf 1997b).

Even though pensions comprised the largest share of the social insurance bill and policy makers had reined in the medical inflation of the 1970s, health care costs remained a concern. Indeed, health care costs began to accelerate again from the late 1980s, and Germany had the dubious honour of ranking second in the OECD in health spending (OECD 1997b: 68-71; OECD 1998e). While some of the rise in expenditures lay in demographic developments and the costs of unification, inefficiencies within the health sector itself were also responsible. Chief among these was the per-diem reimbursement of hospitals, which encouraged unusually long in-patient stays. Another was the imbalance in the relationship between doctors and insurers. Corporatist self-governance was premissed on the KVs and sickness funds being in rough balance so that each could act as a counterweight to the other. But the reality was different. The KVs exploited their monopoly position in the face of a fragmented insurers side to negotiate generous fee settlements (Stone 1980). Thus, if record joblessness made it difficult to justify slashing unemployment insurance or early retirement pensions, the health sector seemed long overdue for efforts to seek out economies (Hinrichs 1995). 
The Kohl Government's health care cost-containment strategy involved a mixed menu of delegating new policy tasks to corporatist actors, a careful experiment with market competition, and limited cost-sharing by patients. The 1988 Health Care Reform Law (GRG) relied on the usual method of corporatist delegation of policy tasks to doctors and insurers. Thus, the law required payers and providers to follow the goal of stable contribution rates in their collective agreements on remuneration, and mandated doctors' and insurers' associations to negotiate maximum prices for pharmaceuticals as well as practice guidelines with which to monitor physician prescribing and ensure that doctors practised cost-effective and clinically consistent medicine. The GRG also introduced minor co-payments on prescription drugs and hospital stays. But insurance contributions continued to rise, and the Kohl Government blamed the doctors for refusing to implement many aspects of the law.

Frustrated with the apparent failures of corporatist self-governance, the government passed the Health Care Structural Reform Law (GSG) in 1992. With this law, policy makers invoked their reserve powers to suspend doctors' and insurers' self-governance rights. Thus, the health ministry set budgets by decree for all areas of the health care system for three years, mandated a two-year price freeze for prescription drugs, and forced the medical associations to assume financial liability for cost overruns in physician prescribing. The law also promulgated slight increases in patient co-payments. Most important, the law introduced market competition among payers. Beginning in 1997, all patients were granted free choice of insurer. But a financial riskadjustment scheme among sickness funds preceded choice of insurer in order to level the playing field among funds with very different health risks.

However, Kohl was not eager to have the state permanently enmeshed in the administrative domain of doctors and insurers. But neither could he afford a cost surge in the health sector once the budgets were lifted. ${ }^{21}$ Kohl's answer to this dilemma was the two Health Care Restructuring Laws of 1997 (NOG 1 and 2). Under the NOGs, the state retreated from setting budgets for most subsectors of the health care system, returned to free collective bargaining between the KVs and insurers, and even extended the scope of their negotiations to the setting of practice guidelines for other subsectors of the health care system. But even as the government reiterated its commitment to corporatist self-governance, it compensated for the lifting of budgets on providers with a greater reliance on market competition among insurers and cost-sharing by patients. Hence, the NOG required that if a fund raised its contribution rate, it would have to increase its co-payments by the same

${ }^{21}$ As a short-term response to employers, the government enacted the Contribution Relief Act (Beitragsentlastungsgesetz) in 1996. That law required all funds to cut their contribution rates by $0.7 \%$ for 1997 (OECD 1997b: 85). 
percentage. But patients facing a hike in contributions and co-payments would be free to switch insurers without the usual waiting period. In effect, the government's budgeting policy shifted from the sectoral level to that of the individual sickness fund. ${ }^{22}$ The government reasoned that this would put sickness funds under severe pressure to not raise their rates and to instead take a tougher line in their negotiations with providers. Finally, the government also introduced provisions that required greater cost-sharing from patients: co-payments were now to be linked to the development of wages and salaries, while marginal benefits were struck from the statutory insurance catalogue and offered as 'extras' for patients to purchase from insurers. ${ }^{23}$

The NOGs signalled a shifting of the burden of cost containment onto patients and insurers. But they were far less drastic than some of the proposals considered during the reform debates between 1995 and 1997. The key goal was to relieve employers' of their share of non-wage labour costs. The most radical proposal would have called for employers' exit from financing health insurance altogether and substituting parity financing with compulsory, individual insurance borne solely by workers. However, a 'wage subsidy' would have compensated employees for this new expense. ${ }^{24}$

This proposal failed, however, not only because unions and the Social Democratic Party (SDP) predictably opposed it, but also because employers themselves had little interest in it. Employers argued that the Free Democratic Party (FDP) proposal would not have solved the problem of labour costs, but would have merely shifted the battle to the collective bargaining arena, where unions would have certainly demanded higher wages as compensation for the substantial new health insurance costs borne by their members ('Haarscharf' 1995). Furthermore, employers reasoned that relief from the responsibility of financing health care would also mean losing their representation on sickness funds' boards and their ability to influence health policy more generally ('Haarscharf' 1995). Finally, the coalition government itself was by no means of a common mind on the proposal. The CDU's trade union wing was adamantly opposed to it on the grounds that it violated the principles of parity financing and administration of health

${ }^{22}$ Manow has made this point in Giaimo and Manow (1999).

${ }^{23}$ The 1996 Contribution Relief Act removed the marginal benefits from the statutory catalogue. For details on the 1997 laws, see Dienst für Gesellschaftspolitik (20 Feb. 1997 and 27 Mar. 1997); Giaimo 1998; Giaimo and Manow 1999; and Manow 1997b.

${ }^{24}$ The strongest backer of this proposal was the Free Democratic Party in Kohl's coalition government. 'Union und FDP geben einander die Schuld am Abbruch der Gespräche über die Gesundheitsreform', Frankfurter Allgemeine Zeitung (FAZ), 9 Oct. 1995, 1-2; 'Wettbewerb zwischen Krankenkassen soll verstärkt werden', FAZ, 15 Dec. 1995, 1; 'Haarscharf wieder so', Der Spiegel, 23 Oct. 1995, 30-1. The reform debate also considered more solidaristic proposals (such as taxing sources of income beyond wages and salaries, or bringing in segments of the population exempt from statutory insurance). For a discussion of the range of proposals considered between 1995 and 1997, see Giaimo 1998; Hinrichs 1995: 637-79; Advisory Council for the Concerted Action in Health Care 1995: 44-7, and 1997: 32-46). For a recent discussion of reform alternatives, see OECD $1997 b$. 
care, while the health minister was fundamentally at odds with the FDP's neoliberal vision of individual responsibility and market provision for health care ('Die FDP unter Druck', FAZ, 9 Oct. 1995, 1; 'Haarscharf' 1995).

The interactions among actors in the German health care system, the broader political economy, and the political arena thus produced an overall reform pattern during the Kohl era that required a balancing of the goals of cost control with equity. All three arenas affected the strategic calculations of payers and policy makers and made it difficult for any one actor to pursue cost containment at the expense of other players. The health care system itself has limited the room for manoeuvre of employers, but so has its relationship to the larger political economy. Thus, the statutory nature of health insurance did not allow employers to reduce their labour costs by refusing to provide health insurance or by unilaterally curbing benefits. Moreover, even when given the option of exit, employers refused to take it because they recognized that they face a formidable counterweight in employees' presence in health insurance financing and administration, as well as in union strength in collective bargaining. ${ }^{25}$ Business leaders knew that victory in one arena could just as easily translate into setbacks in another, and they saw their role in statutory social insurance as a valuable lever to control non-wage labour costs.

The German political system also granted key health care stakeholders a number of avenues to shape the content of reform legislation. The political parties and federalism were the chief avenues of influence for employees as well as employers. Both of the two main political parties - the Christian Democratic Union (CDU) and the SPD are heterogeneous Volksparteien or 'catch-all parties' (Kirchheimer 1966) representing the interests of employees and vulnerable groups in the population. The CDU institutionalizes both a business and Catholic trade union wing in separate internal party committees. The trade union wing of the CDU, with jurisdiction over the party's social policy matters, was the driving force behind the hardship exemptions on co-payments that featured in all of the health care reform laws. The GSG's measures reducing the disparities in choice of insurer and in contribution rates between blue- and white-collar workers were the product of a cross-party deal between the CDU's trade union wing and the opposition SPD in 1992. This 'de facto grand coalition' between the CDU and SPD was an expression of federalism and the Social Democrats' majority in the legislative upper house (Bundesrat), as well as of the ideological affinity between the CDU's labour wing and the SPD's moderate wing on the social market economy (soziale Marktwirtschaft) and a comprehensive welfare state.

${ }^{25}$ German unions only organize $35 \%$ of the labour force, but state extension of collective agreements grants them far more influence than membership numbers would suggest. Unions and employees are also firmly entrenched in the governance of the firm through co-determination arrangements. 
But health politics and policies also were shaped by electoral outcomes and coalition politics. Encouraged by its improved showing in state elections in 1996, the FDP became a more pugnacious coalition partner eager to distinguish itself from the CDU and refusing to countenance further deals with the SPD. On top of this, Kohl's Government had only a razor-thin majority in the lower house (Bundestag) after 1994. To keep his fractious coalition together, Kohl had to yield to the FDP more than he had in the past. With the NOGs, then, the FDP played its familiar role as the patron of physicians and small business. Along with pressure from the CDU's business wing, whose influence had increased as the economic climate had deteriorated, Kohl chose the NOGs' provisions to stabilize employers' labour costs at the expense of patients and sickness funds.

Finally, the national insurance system both constrained and empowered state actors in the task of health care reform. Because national insurance guarantees all persons the same access to services based on medical need, and is modelled on contributory social insurance, it is very difficult for the state to pursue austerity at the expense of any one class or subgroup of the population. At the same time, however, the corporatist arrangements in the national insurance system provide the state with the legal authority and the institutional means - through its leverage over public-law bodies - to mandate cost-containment tasks on health care actors and to set the terms of market competition in ways that do not compromise the equity and solidarity of the system.

How, then, should we judge the Kohl Government's record on balancing costs and equity? Had they been fully implemented, it is clear that the NOGs would have shifted the burden of welfare state and economic adjustment from employers to patients. Dynamized co-payments and the linking of contribution to co-payment increases implied a gradual movement away from the principle of parity financing, since employees already paid half of the insurance contribution and patients would have also had to assume a growing portion of health care costs out of their own pocket (Manow 1997b).

But in important respects, the Kohl Government's policies largely preserved the equity of the health care system, and in some cases, even extended it. Health insurance has remained universal and the statutory catalogue of benefits generous; the services struck from the catalogue in 1996 were quite marginal. Hardship clauses have exempted low-income persons from the co-payment requirement or otherwise set a ceiling on the amount that those with chronic conditions would have to pay. And the government designed market forces in such a way as to advance both efficiency and equity concerns. Thus, insurers cannot compete on the basis of fewer benefits to woo healthier members but instead must accept all applicants and must offer, at a minimum, the same health services to all members contained in the catalogue of statutory benefits. Significantly, competition has granted wage 
earners nearly identical rights of choice of insurer as those long enjoyed by salaried employees. Likewise, the risk adjustment scheme has required substantial financial transfers from the company and white-collar funds, which had a history of healthier and wealthier members, to the local funds, which had had to levy higher contributions to cover the health care costs of their poorer and sicker blue-collar members. The risk-adjustment scheme has also narrowed contribution rates considerably among funds, to the benefit of bluecollar workers. ${ }^{26}$ The risk-adjustment programme also reduces the temptation of sickness funds to compete by cream-skimming the healthier and wealthier persons, since they know they will have to make payments to funds with poorer health risk profiles. Finally, the most controversial provisions of the 1997 laws did not get very far in practice. Fearing punishment from voters in the 1998 elections, the Kohl Government refrained from implementing the provisions linking co-payments and contributions, while Kohl's Social Democratic successor, Gerhard Schröder, suspended the dynamization of co-payments and other market-like measures (Manow 1997b; Schneider 1998). ${ }^{27}$

Under Kohl's watch, the cost performance of the German health care system has also been respectable. To be sure, health insurance contribution rates have risen nearly every year, but the pace has been moderate: the average contribution rate, which stood at 12.6 per cent in 1990 , was only 13.6 per cent in 1996 (Manow 1997a: table 3), despite the burdens of an ageing population, recession, and unification. This is not to say that Germany has found a way to permanently halt the upward trajectory of health care spending. But it has so far held the line and should be seen as an intermediate case between the tight-fistedness and unmet demand of Britain and the profligacy and cost-shifting of the United States.

\section{The United States: The Triumph of 'Unmanaged Competition' and the Defeat of Equity}

The most striking feature of the American health care system is the absence of a statutory universal health care programme and an employmentbased fringe benefits system in its stead. Most Americans look to their employers to provide health insurance, while public programmes are confined

${ }^{26}$ One fund, for example, had to pay approximately half of its revenues to the risk adjustment fund (OECD 1997: 107). In 1993, approximately $32 \%$ of funds levied contribution rates $1 \%$ above or below the average. In 1996, less than $10 \%$ of the funds did so (Ministry of Health, cited in Giaimo and Manow 1999: 982).

${ }^{27}$ Kohl's successor, Gerhard Schröder, announced upon taking office that his SPD-Green government would not introduce the linkage provisions, and abolished the provision for dynamizing co-payments and some of the other market-like mechanisms, such as premium rebates for healthy patients, that the 1997 laws had introduced. The Schröder Government also reimposed legal budgets on all subsectors of the health care system as an interim cost control measure until it devised a comprehensive reform scheduled for the year 2000 (Schneider 1998). 
to designated categories of the population, such as the elderly, disabled, the military, and the very poorest in society. Such arrangements make employers the pivotal players in the health care system and health care politics. They are free to decide whether or not to provide insurance as a fringe benefit, and when they do, most companies pay the bulk of the insurance premium (at least of the cheapest health plan). Unions offer little in the way of countervailing power because they have little or no presence in the workplace and no role in welfare state administration. ${ }^{28}$ Likewise, government actors have few mechanisms to control the behaviour of employers and insurers in a voluntary, private fringe benefits system. State governments have limited regulatory authority over the employment-based insurance sector, while the federal government's reach is even more at arm's length.

Because of this patchwork system, the US health care system has always been plagued by costly gaps in access. The uninsured had access to emergency hospital care, and the safety-net providers who treated them recouped their losses by charging patients with private insurance higher fees. Insurers, in turn, passed on their cost increases to employers by charging them higher premiums (Reinhardt 1992). Thus, an elaborate but largely hidden cost-shifting game was being played, but with only some employers footing the bill. Rationing access by ability to pay was both inequitable and inefficient: it burdened vulnerable groups in society, encouraged free-riding by less efficient firms, and discouraged the uninsured from seeking out less expensive preventive care instead of costly hospital care.

But other reasons besides gaps in access and resultant cost-shifting were behind the high costs of the US health care system. Most physicians received fee-for-service payments for their services while hospitals were reimbursed for their costs, which gave them little incentive to seek out less expensive alternatives. Insurers largely paid what doctors billed without questioning treatment decisions, thereby deferring to physicians' economic and clinical freedom. The USA never had a mechanism like global budgeting to limit overall health care expenditures. Nor was there an effective system for controlling the diffusion of medical technology. ${ }^{29}$ And until the advent of managed care, the USA had no gatekeeper system to limit access to specialists or to hospitals.

The cost-shifting game did not arouse too much complaint from employers as long as the economy kept growing and American businesses were shielded from the effects of competition. But a number of factors converged to undermine firms' willingness to underwrite the care of the uninsured. First, medical inflation began to rise steeply in the 1980s (see Table 11.4).

${ }^{28}$ There are some exceptions, however. Some unions finance and administer insurance funds for their members. And employers who choose to self-finance their own health plans may directly administer these plans. But in many cases, employers contract with an insurance company for administration.

${ }_{29}$ On state efforts to control high technology in hospitals, see Russell 1979. 
TABLE 11.4. Changes in medical care costs compared to Consumer Price Index, US $(1967=100)$

\begin{tabular}{lrrrr}
\hline Year & CPI & Total Medicine & Hospital & Physicians \\
\hline 1960 & 88.7 & 79.1 & 57.3 & 77.0 \\
1965 & 94.5 & 89.5 & 75.9 & 88.3 \\
1970 & 116.3 & 120.6 & 145.4 & 121.4 \\
1975 & 161.2 & 168.6 & 236.1 & 169.4 \\
1980 & 246.8 & 265.9 & 418.9 & 269.3 \\
1985 & 326.6 & 413.0 & 722.5 & 407.9 \\
1990 & 421.8 & 592.9 & 1096.1 & 533.1 \\
1995 & 491.4 & 817.6 & 1577.1 & 692.5 \\
1996 & 512.5 & 847.8 & 1638.6 & 717.0 \\
\hline
\end{tabular}

Source: Peters 1999: 251: Bureau of the Census, Statistical Abstract of the United States.

Employers' health insurance premiums escalated at double-digit annual rates in the 1980s; between 1987 and 1993, employers' insurance premiums rose 90 per cent (Cooper and Schone 1997: 142).

More tellingly, the spike in health care inflation coincided with broader changes in the American economy since the 1970s. The shift to a postindustrial economy brought with it the disappearance of unionized jobs in manufacturing that had come with generous fringe benefits. In their place arose service sector jobs, temporary positions, and subcontracted labour in both manufacturing and services. Such contingent labour was one of the chief means for employers to hold down their labour costs, since these jobs often paid much lower wages than unionized jobs in manufacturing and did not come with health insurance and other fringe benefits (R. Freeman 1994). ${ }^{30}$ Thus, the shifts in the American economy swelled the ranks of the uninsured, adding to the cross-subsidy burden of employers who did provide insurance. As their health insurance bills rose, these firms complained that they were at a competitive disadvantage relative to their domestic rivals who did not provide insurance, or to those foreign competitors with lower labour costs.

As the 1980s wore on, employers who provided insurance became less willing to shoulder the access and cost deficiencies in the health care system. Many of them began to look to government to relieve them of their crosssubsidy burden through a national health insurance solution (C. J. Martin 1995a). Those advocating national insurance found a sympathetic ally in President Bill Clinton, who wanted to control the costs of public insurance

30 The proportion of uninsured Americans had declined throughout the $1960 \mathrm{~s}, 1970 \mathrm{~s}$, and the 1980 s as a result of the expansion of Medicare, Medicaid, and employer-based insurance. However, the downward trend began to reverse itself in the late 1980s. Most of the uninsured were those in the labour market (Banks, Kunz, and Macdonald 1994: 19). In 1987, 14.8\%, or 31.8 million non-elderly Americans had no insurance. By 1995, that figure had risen to $17.4 \%$ of the non-elderly population, or 40.3 million persons (EBRI 1997). 
programmes, address employers' competitiveness concerns, and stem the rising tide of the uninsured.

With his plan for national health insurance and government-structured market competition, Clinton sought to solve both the cost and access problems simultaneously. ${ }^{31}$ First, Clinton's Health Security plan would have required all firms to provide insurance, with the government subsidizing the costs to small firms or those individuals unable to obtain insurance through the workplace. Pooling all risks within a national insurance system would have achieved universal access and ended the cost-shifting and free-riding by firms that did not provide insurance. Second, Health Security mandated market competition among both providers and insurers to control health care costs, while largely pinning its hopes on health maintenance organizations (HMOs) to bring cost discipline to the market. By restricting patients' access to hospitals and specialists, HMOs tended to be much cheaper than other types of health plans. More expensive insurers would either have to reduce their costs to retain patients or else charge higher premiums and impose cost-sharing for additional benefits or greater choice of provider. ${ }^{32}$

Third, government actors would have played a leading role in structuring the market to ensure universal access and to prevent insurers and providers from engaging in competitive practices that harmed the sicker and poorer. States would have been key actors in this regard by establishing quasi-public 'health alliances' on a regional basis to ensure that small businesses and individuals had access to affordable coverage. In short, alliances would have organized the market and 'managed' the competition through extensive monitoring of insurers to prevent them from cream-skimming (Starr 1994: 53, 102). Large companies that self-insured could have chosen to opt out of the state alliances and instead constitute their own alliances (C. J. Martin 1995b).

Finally, the Clinton plan would have expanded the federal government's reach over employment-based insurance. The Health Security Act would have legislated a minimum but comprehensive benefits package that all plans had to offer. In addition, a National Health Board, with members appointed by the President, would have possessed wide-ranging powers to regulate alliances and health plans. And because the Clinton administration doubted that competition alone could control costs, the National Health Board would have had the authority to enforce a global budget cap over the entire health care system by limiting insurers' premium increases to the rate of inflation (Starr 1994).

${ }^{31}$ Unless otherwise noted, the description of the Clinton plan is drawn from the White House Domestic Policy Council (WHDPC 1993). Clinton's plan drew heavily on Stanford health economist Alain Enthoven's theory of managed competition (see Enthoven 1988, 1993).

${ }^{32}$ Employers would have shouldered $80 \%$ of the premium of the cheapest plan, with employees paying the $20 \%$ balance plus any additional premium costs if they chose more expensive plans. 
Clinton's effort to introduce national health insurance came to an inglorious end, but this did not mean that health care reform was dead. Rather, transformation of the health care system continued apace at breathtaking scope and speed, with employers leading the charge in an uncoordinated, every firm-for-itself strategy. The centrepiece of this strategy was the deployment of competition against insurers and providers. Under pressure from employers to hold the line on premiums, managed care plans negotiated steep price discounts or capitation arrangements with doctors and hospitals. ${ }^{33}$ Many employers also sought to control their health care costs by offering workers only one health plan, often an inexpensive HMO. Others rushed to self-insure in order to escape state risk-pools for the uninsured and other consumer regulations. In addition, employers engaged in a number of strategies that shifted their costs onto weaker market actors. For instance, companies required their workers to shoulder a greater share of insurance premiums or co-payments or curtailed the range of benefits that health insurance plans offered. Finally, some companies exercised their ultimate exit option by refusing to provide coverage at all (Giaimo 1996; Giaimo and Manow 1999).

Employers' strategies to contain their labour costs are best characterized as 'unmanaged competition' (Giaimo 1996), in which the application of market forces in health care has proceeded in the absence of an effective regulatory framework that would prohibit or compensate for market failures. Federal and state government controls over employers' and insurers' cost-cutting practices have been piecemeal, weak, or non-existent. Where government action has occurred, it has largely taken the form of incremental regulation of the insurance market to foster competition, as with federal and state oversight of mergers (Given 1997), or to make it conform to the dictates of the larger economy (Giaimo and Manow 1999). ${ }^{34}$ The absence of a framework of rules over the market has permitted insurers to continue to segment the market and shun the worst health risks. And the absence of effective consumer protections in the world of managed care has also provoked a public backlash against the rationing decisions of HMOs (Blendon et al. 1998).

${ }^{33}$ By $1997,85 \%$ of employees were in some type of managed care plan, up from slightly more than $28 \%$ in 1988 (Milt Freudenheim, 'To Economists, Managed Care is No Cure-All', New York Times, 6 Sept. 1994, A1, A10; Freudenheim, 'Health Insurers Seek Big Increases in their Premiums', New York Times, 24 Apr. 1998, A1, C4). For an excellent survey of recent managed care developments, see.Wilkerson, Devers, and Given 1997: esp. ch. 1 and conclusion chapter. The editors point out that while managed care plans have a long history, the phenomenon of intensified price competition among these health plans is a recent development.

${ }^{34}$ The 1996 Kassebaum-Kennedy Act was an attempt to respond to employers' concerns with 'job-lock' by barring insurers from denying coverage to new employees with pre-existing medical conditions. But because the law made no provision that premiums would be affordable and allowed insurers to impose a waiting period before coverage began, it fell far short of its goal (Fuchs et al. 1997; GAO 1998; Robert Pear, 'Clinton to Punish Insurers Who Deny Health Coverage', New York Times, 7 July 1998, A1, A13). 
How can we understand a reform path that started out as a solidaristic attempt at national insurance but ended up as atomistic cost-shifting at the expense of broader solidarity? The explanation lies in the critical role played by employers, their inability to forge a common line around a solidaristic solution to their labour costs problem, and the voluntarism of the fringe benefits system that instead encouraged their go-it-alone strategies of cost containment. Employers were critical to the fate of the Clinton plan because they financed health insurance and would have continued to do so under Health Security. As a result, the Clinton plan was held hostage to the veto of business. Firms' disarray in the political arena mirrored their actions in the health care system itself, with employers organizationally incapable of delivering support to the President. Moreover, the voluntarism of the American health insurance system encouraged employers to pursue multiple go-it-alone cost-containment strategies and blocked effective government action to limit their behaviour in ways that would protect solidarity. Let us consider each of these points in turn.

First, a firm's particular position in the health care system shaped its approach to controlling labour costs and the attitudes of its managers towards reform. For some employers, the voluntarism of the fringe benefits system aided them in their quest for low labour costs, but for others, it was a big part of the problem. As we have seen, many employers who already provided insurance blamed their high labour costs on the free-riding of their colleagues who did not offer coverage, and supported national insurance to level the competitive playing field among them. Most small businesses, by contrast, saw the voluntarism of employment-based insurance as vital to their economic survival; the freedom to not provide insurance was what allowed them to keep their labour costs at competitive levels. Not surprisingly, they vehemently opposed the Clinton plan on the grounds that it would saddle them with ruinously high labour costs. But even among firms that provided insurance, there were those who rejected the Clinton plan because they feared that it would have meant higher costs. Either they would have been forced into regional alliances and would have paid higher premiums in order to subsidize insurance for small businesses. Or, if they were large enough to constitute their own alliances, they ran the risk that the even larger regional alliances would have negotiated better rates from insurers and left them with higher premiums (Judis 1995; C. J. Martin 1995a, 1995b). For different reasons, then, these employers believed they could better control their own costs by 'going-it-alone'.

Second, the business community proved incapable of forging a common line on health care reform, in large part because the health care system granted its member firms multiple ways to control their labour costs, including not providing insurance at all. The freedom of action in the health care system, in turn, aggravated employers' collective action problems in the political arena. 
Employers' peak associations - perennially weak, fragmented, and lacking sanctions over recalcitrant members - proved unable to overcome the centrifugal tendencies within their ranks to rally their members to support the Clinton plan at the critical legislative stage. Associations representing large and medium-sized firms remained on the sidelines and left the field open to small business, whose association waged a highly effective campaign of opposition. ${ }^{35}$ Third, many businesses deemed Clinton's attempt to claim a greater government role in employment-based insurance as an illegitimate intrusion into their domain of corporate governance. Some employers - and not just small businesses - opposed Clinton's national insurance proposal because the employer mandate and statutory benefits package would have encroached upon their freedom to decide on insurance coverage for their employees. Others were even more alarmist, arguing that national insurance was an entering wedge for government intrusion into other areas of corporate governance (Judis 1995).

Subsequent government attempts to regulate the health care market after the Clinton plan's defeat have met with similar failure. Employers and insurers continue to regard government efforts to regulate employer-based health plans as illegitimate and as saddling them with unwanted costs. Moreover, the perversities of federalism have meant that state and federal officials work at cross-purposes, blocking one another's efforts to expand access or enact adequate consumer protections on employment-based insurance. The biggest obstacle is the Employee Retirement and Income Security Act (ERISA), which permits states to regulate private insurance but not employers' self-insured health plans. Not surprisingly, employers have seized upon self-insurance to avoid cooptation into state risk-pools for the uninsured and to evade state consumer protection regulations for private insurers. At the same time, however, federal regulation of self-insured plans and employer-based health insurance more generally is notoriously weak. The result is a dual system of government regulation that shields self-insured plans - whose numbers are increasing - from regulations that apply to other types of private insurers. ${ }^{36}$

${ }^{35}$ For accounts of business organizations' disarray towards the Clinton plan, see Adam Clymer, Robert Pear, and Robin Toner, 'For Health Care, Time Was a Killer', New York Times, 29 Aug. 1994, A1, A8-9; Judis 1995; Jurek Martin, 'Business Snubs Clinton Health Bill', Financial Times, 4 Feb. 1994, 5; Skocpol 1996; and Robin Toner, 'Autopsy on Health Care', New York Times, 27 Sept. 1994, A1 ff.

${ }^{36}$ For a discussion of ERISA, see Acs et al. 1996; Chirba-Martin and Brennan 1994; GAO 1995; Grogan 1995; O'Keefe 1995; and Polzer and Butler 1997. Seventy-eight per cent of companies with 1,000 or more employees and $89 \%$ with 20,000 or more employees were self-insured in 1993. Self-insurance has been growing: among firms with at least 100 employees, $46 \%$ of employees were enrolled in self-insured plans in 1993, compared to only $28 \%$ in 1986 (GAO 1995: 12-13). The Clinton administration had pushed for comprehensive consumer protection legislation at the federal level to regulate the rationing decisions by HMOs. But its efforts became bogged down in the impeachment scandal (see Giaimo and Manow 1999; R. Pear, 'Senators Reject Bill to Regulate Care by HMOs', New York Times, 10 Oct. 1998, A1, A8). 
Health care reform through the market, led by private actors in the absence of public rules, has worrying implications for the achievement of both cost control and equitable access and financing. On the positive side, the USA experienced a noticeable slowing in health care outlays between 1993 and 1996. The spread of managed care plans in the private sector, with their restricted access to hospitals and specialists and their reliance on capitation or discounts to pay providers, has wrung out much of the excess capacity in the health care system and is responsible for much of the slowdown in health care outlays (Levit et al. 1998; S. Smith et al. 1998). However, it may be that the days of easy savings have come to an end, as mergers and acquisitions among plans and providers reach a saturation point (S. Smith et al. 1998). Indeed, after slowing considerably in the last few years, employers' health insurance premiums are set to rise substantially, as insurers seek to recover lost profits after years of belt-tightening. ${ }^{37}$

Moreover, cost savings for some have been realized at the expense of equity. While insurers have recently hiked their premiums, the biggest increases have fallen on small firms and individuals, not large companies. ${ }^{38}$ In addition, firms' and insurers' cost-cutting strategies have segmented the market further and threaten what little solidarity there is in the health care system. The current trend shows the number of uninsured growing as employers - willingly or otherwise-exercise their exit option and refuse to offer coverage or as low-wage workers find insurance premiums beyond their reach (Cooper and Schone 1997). Those individuals with insurance coverage are also bearing a greater share of their health care costs. Finally, continued cost-shifting to weaker market players only aggravates the problem of the uninsured, as small firms and individuals find themselves priced out of the market by exorbitant premiums. The 'worst case' scenario predicts the disintegration of public hospital 'providers of last resort' and more restricted access for the most vulnerable members of society as employers' and insurers' costcutting actions, along with cuts in government programmes, destroy the cross-subsidy for the uninsured. ${ }^{39}$ Thus, absent effective public intervention,

${ }^{37}$ Real per capita health spending averaged just below 5\% per year between 1970 and 1993. Between 1993 and 1996, it averaged only $1.5 \%$ per year. But it is set to grow at $3.4 \%$ per year from 1997 to 2007 , with the percentage of GDP predicted to rise to $16.6 \%$ in 2007 (S. Smith et al. 1998: 128-9).

${ }^{38}$ Milt Freudenheim, 'Health Care Costs Edging Up and a Bigger Surge is Feared', New York Times, 21 Jan. 1997, A1, D20; Freudenheim, 'Health Insurers Seek Big Increases in their Premiums', New York Times, 24 Apr. 1998, A1, C4. In addition to cost-shifting from stronger to weaker market players, the higher costs may be due to patients demanding greater choice of physician, and doctors organizing to counteract the growth of HMOs.

39 For evidence of the 'worst case' scenario and the threat to the public hospital system, see the Los Angeles Times series in October 1995. Reinhardt (1995) paints a somewhat less pessimistic portrait, but one that still envisions safety-net providers bearing the brunt of the burden. 
the ultimate logic of employer-led, go-it-alone strategies threatens both the cost-containment goals of many individual firms as well as the survival of the health care system itself.

\section{CONCLUSION}

The health care reform experiences suggest broader lessons for the politics of welfare state adjustment in the twenty-first century. The first lesson is that payers have become the driving force behind reform and they are likely to remain important actors in the politics of welfare state adjustment as long as economic difficulties associated with globalization or the post-industrial economy continue. But this should not lead to the conclusion that their views will always prevail. The terms of welfare state adjustment will depend on the presence of countervailing forces in the particular welfare state and political arena in each country.

Second, employers (and governments) are undeniably worried about the welfare state's effects on competitiveness. But their concerns need not translate into a policy stance that is anti-welfare state or anti-solidaristic. As the accounts of health care reform in the USA and Germany illustrate, many companies may favour a statutory, solidaristic solution because it pools risks and levels the competitive playing field among them. This suggests that employers' views towards the welfare state will depend on whether they see it as compatible with their competitiveness strategies. The strategies employers choose to contain their labour costs, in turn, will in part depend on the type of welfare state in which they find themselves and the freedom of action it grants or denies them to do so.

Thus, there is no one welfare state that best serves the cause of competitiveness, or even one particular welfare state type that automatically corresponds to a particular political economy. Instead, a number of different welfare state regimes may 'fit' together with the other components of a nation's political economy. ${ }^{40}$ Thus, a voluntary fringe benefits system like that in the USA is an integral part of a broader liberal political economy, and is a critical part of a strategy of competition based on rock-bottom prices and low skills/low labour costs because it allows firms the freedom to not provide benefits. Of course, it also creates difficulties for other firms who must

${ }^{40}$ Put another way, there may be more 'varieties of capitalism' than the literature commonly assumes. The varieties of capitalism literature sketches only two models of capitalism: coordinated and liberal market economies. And it is only beginning to systematically integrate welfare states into its analysis. For examples of the varieties of capitalism literature, see Crouch and Streeck 1997; Hall 1998. For efforts to integrate the welfare state into varieties of capitalism models, see Ebbinghaus and Manow 1998; and Manow $1997 a$. 
subsidize their compatriots' free-riding. The danger is that free-riding will gradually undermine this form of social provision, as more and more employers drop coverage to contain their labour costs.

But a tax-financed, state-administered system like the British NHS can be equally compatible with company strategies to compete on low prices and labour costs characteristic of a liberal political economy. Indeed, one reason that a social democratic oasis like the NHS could survive in Britain's neoliberal desert - aside from its track record of delivering low health care spending and its broad political popularity-was precisely because it did not threaten a competitiveness strategy premissed on low price and labour costs that Thatcher and employers advocated. A social insurance system like Germany's would seemingly pose the biggest disadvantage for firms seeking competitiveness through lower labour costs. Yet, as we have seen, employers have not been eager to part with their role in the social insurance system because it has provided them a lever over labour costs outside of collective bargaining. ${ }^{41}$ This is a considerable advantage in a political economy that features a strong union presence in both industrial relations and in welfare state administration.

Third, some of the arguments advanced in welfare state reform debates argue for a roll-back of government and more privatization. But the health care reform experiences show that employment-based fringe benefits systems are a poor substitute for statutory social insurance programmes. As EspingAndersen (1990) has noted, different welfare state regimes embody different kinds of social rights. In statutory universal systems, social rights are broadly defined and firmly anchored in the law. In fringe benefits systems, however, social rights rest on a precarious foundation. They depend on the economic power of unions to secure them through collective bargaining or on the discretion of employers to provide them, and generally do not have the legal backing of the state. This is not to imply that universal, statutory programmes are immutable or permanent, or that they should not or cannot adapt to new realities. But they may be harder to dislodge because they have a broader spectrum of the population interested in preserving them. And because they incorporate redistribution within their design, they may prove better able to adapt in ways that safeguard equity.

The task for all advanced industrialized societies is to adapt their welfare states to new economic and demographic challenges in ways that reconcile efficiency with equity. However, the outcome is likely to be quite different in welfare states with different kinds of social rights and social forces. Private

${ }^{41}$ Mares (1997a) and Swenson (1997) likewise found that firms have good economic reasons for wanting universal social programmes. Employers may also value their administrative role in social insurance if it provides them with a painless way to rationalize production and shed unneeded labour onto the broader risk community (see Manow 1997a; Visser and Hemerijck 1997). 
fringe benefits systems appear to have a bleak future. Lacking countervailing forces to challenge or curb employers' freedom to pursue exit options, the anchoring of social rights in the law, or a broad notion of solidarity that ties people to a common fate, such systems will likely to continue down the path of desolidarity, unless those bearing the brunt of cost-shifting and economic adjustment can muster the political clout to seek a negotiated solution that advances equity alongside austerity.

The outcomes may be more hopeful in universal, statutory systems. If, as seems likely, economic and demographic pressures continue to strain the finances and generosity of such welfare states, then governments and employers will be hard-pressed to seek solutions that redefine solidarity and the content of social rights. But given the presence of powerful countervailing forces in such welfare states and reform politics, successful adjustment will hinge on forging a consensus with these stakeholders over a new conception of solidarity that continues to ensure broad provision, spreads the burden of adjustment fairly, and shelters the most vulnerable from harm.

There is no reason to expect countries to converge on a common path of welfare state adjustment. There are several possible options. ${ }^{42}$ Each country's outcome will depend not only on past 'policy legacies' (Pierson 1993b; Weir and Skocpol 1985), but also on political choice and the particular settlements that stakeholders are able to forge among themselves.

${ }^{42}$ Future choices in health care reforms - and how they are viewed - will depend on the particular problems facing each type of health care system and the specific politics of reform in each country. For example, countries with universal health care provision might decide to adopt a defined benefits package that is mandatory, universal, and comprehensive, but that explicitly spells out the services that the national programme will cover. Individuals with the means to do so could then purchase extra benefits at an additional charge, but the most vulnerable would still have a right to fairly comprehensive coverage. Such a remedy, however, would officially sanction some differences in access based on ability to pay and may imply a stricter delineation of medical necessity. British and German citizens might view this solution either as a violation of solidarity, or as an attempt to redefine it to reconcile equity and cost containment goals. But if the USA adopted a defined benefits package as part of national health insurance, it would clearly signal a reversal of desolidarity. See Brown (1998) for a discussion of different health care reform options that European countries are contemplating or have recently adopted. See Advisory Council for Concerted Action in Health Care $(1995,1997)$ for a discussion of reform options for Germany. On redefining medical necessity to fit new policy goals, see Charles et al. (1997). 